\title{
Question of Optimal Cutting Speed for Machining by Conventional and Coated Cutting Tools
}

Karol Vasilko, Zuzana Murčinková

Faculty of Manufacturing Technologies, Technical university of Košice with a seat in Prešov, Bayerova 1, 08001 Prešov, Slovak Republic. E-mail: karol.vasilko@tuke.sk, zuzana.murcinkova@tuke.sk

The paper dealt with tool-wear, tool-life and chip creation regarding the cutting speed for machining by conventional and coated tools. The cutting speed is influenced by several parameters. The determination of optimal cutting speed is challenging question. Situation is more complicated in case of coated tools. The important is criterion of optimization. Moreover, the presence of the coating changes chip creation process and stress state during cutting. The paper provides complete experimental $T$ - $v_{\mathrm{c}}$ dependencies obtained in turning regarding various parameters as depth of cut, feed for different machined and cutting tool materials. Paper describes also different toolwear mechanisms of uncoated and coated tools. Finally, the paper analyzes stress state in tool as simplified model of contact of tool rake and chip for conventional and coated tools involving different mechanical properties of coating and substrate material, temperature and different thicknesses of coatings.

Keywords: cutting conditions, turning, tool wear, coating

\section{Acknowledgement}

Authors thank for supporting this research by grant VEGA in project 1/1000/15 to Agency of Ministry of Education of Slovak Republic.

\section{References}

[1] BOHÁČEK, B. et al. (1984). Části a mechanismy strojů. Brno: VUT.

[2] GRZESIK, W. (2010). Podstawy skrawania materialow konstrukcyjnych. Wydawnictwa Naukowo-Techniczne, Warszawa, p.526, ISBN978-83-204-3668-6

[3] KUNDRÁK, J. (2011). Alternative machinining procedures of hardened steels. Manufacturing Technology, No. 11, pp. $32-36$

[4] MÁDL, J., RAZEK, V., KOUTNÝ, V., KAFKA, J. (2013). Surface Integrity in Notches. Manufacturing Technology, No. 2, pp. 188-193

[5] MAMALIS, A, G., KUNDRÁK, J., HORVÁTH, M. (2002). Wear and Tool Life of CBN Cutting Tools. Manufacturing Technology, pp. 475-479

[6] MRKVICA, I., et al. (2012). Cutting ceramic by turning of nickel alloy Inconel. Manufacturing Technology, vol. 13, pp. 178-186.

[7] MURČINKO, J., MURČINKOVÁ, Z. Implementation of intelligent elements in vibration diagnostics of CNC machines. Applied Mechanics and Materials, TTP, Vol. 308, pp. 87-93.

[8] MURČINKOVÁ, Z. (2004). Software localization of maximal subsurface stresses in point contact of 3D bodies. In: New ways in manufacturing technologies 2004, 17th - 18th June, Faculty of Manufacturing Technologies, Technical university of Košice, Prešov, p. 1-4

[9] ŠEBELOVÁ, E., CHLADIL, J. (2013). Tool Wear and Machinability of WOOD-based Materials during Machining Process. Manufacturing Technology, Vol. 13, No. 2, pp. 321-325

[10]VASILKO, K., MÁDL, J. (2012). Teorie obrábění. Ustí n. Labem: UJEP, 526 s., ISBN 978-80-7414-460-8

[11]VASILKO, K. (2009). Teória a prax trieskového obrábania, FVT TU v Košiciach, Prešov

[12]VEREŠČAK, A. S. (1993). Robotosposobnost' instrumenta s iznossostojkom pokrytijem. Moskva, Mašinostrojenije 